\title{
SAMOBÓJSTWO: ŚMIERĆ JAKO PRZEMIANA RADYKALNA
}

The insights of depth psychology derive from soul in extremis, the sick, suffering, abnormal and fantastic conditions of psyche. (...) Perhaps our psychopathology has an intimate connection with our individuality, so that our fear of being what we really are is partly because we fear the psychopathological aspect of individuality. For we are each peculiar; we have symptoms; we fail, and cannot see why we go wrong or even where, despite high hopes and good intentions ${ }^{1}$.

James Hillman

1.

„W próbach udzielenia odpowiedzi na pytanie dlaczego ludzie odbierają sobie życie - czytamy w Leksykonie psychiatrii, dziele mającym stanowić zwarte kompendium współczesnej wiedzy psychiatrycznej - wysuwane są dwie, pozornie przeciwstawne, tezy: że samobójstwo jest przejawem patologii społecznej lub wiąże się z patologią jednostki"2. Tezy te - jak następnie wywodzą autorzy hasła - są przeciwstawne tylko pozornie, ponieważ patologia jednostki pozostaje $\mathrm{w}$ relacji ścisłej łączności i ścisłego sprzężenia z patologią społeczną. A mianowicie: patologiczne środowisko, w którym jednostka przebywa, prędzej czy później zaczyna wywierać na nią zgubny wpływ - i odwrotnie: patologiczna jednostka znajdująca się w zdrowej strukturze społecznej, swoją własną patologią prędzej czy później zaczyna

\footnotetext{
${ }^{1}$ J. Hillman, Re-Visioning Psychology, Harper Perennial, New York 1992, s. 55.

2 S. Pużyński (red.), Leksykon psychiatrii, Państwowy Zakład Wydawnictw Lekarskich, Warszawa 1993, s. 417.
} 
„infekować” otoczenie (a zatem kolejne jednostki). W ten sposób tworzy się swoista spirala patologii. Spirala, której składowe (jednostka i społeczeństwo, indywiduum i jego sytuacja, geny i wpływ otoczenia) tworzą diadę, będącą zgodnie ze współczesnym konsensusem medyczno-psychologicznym - ostatecznym punktem dojścia wszelkich wysiłków diagnostycznych, a w szczególności wysiłków mających na celu ustalenie genealogii zaburzeń psychicznych (których najbardziej dotkliwym, najbardziej wymownym efektem, jest właśnie samobójstwo $)^{3}$.

W horyzoncie medycznym każde samobójstwo jest więc wyrazem patologii, co równoznaczne jest stwierdzeniu, że każdemu samobójstwu należy - przy użyciu wszelkich dostępnych medycynie (a także, jeśli trzeba, policji czy sądom) środków - zapobiegać. W Leksykonie psychiatrii nie tylko nie wspomina się więc ani słowem o suicydalnych rozważaniach Sokratesa, Platona, Seneki czy Schopenhauera - postrzegających samobójstwo jako jedną z możliwości stojących przed człowiekiem, a czasami jako jedyne zgoła wyjście z rozpaczliwego bezsensu życia - ale wręcz same „pozornie abstrakcyjne rozważania o bezsensie życia (...), o problematyce śmierci" ${ }^{4}$ traktuje się tam jako niepokojące symptomy diagnostyczne, których wystąpienie powinno pobudzić medyczną czujność i skłonić lekarza do rozważenia, jakiego rodzaju działania prewencyjne należałoby w związku z tym przedsięwziąć. W książce Samobójstwo a przemiana psychiczna - będącej głównym bohaterem niniejszego szkicu - James Hillman już na samym początku tłumaczy, dlaczego tego rodzaju postawa jest $\mathrm{w}$ obszarze paradygmatu medycznego nieprzekraczalna i niemożliwa do zmiany:

Pierwsze przykazanie lekarza - pisze Hillman - brzmi: Primum nihil nocere - Przede wszystkim nie szkodzić. Jego zadanie polega na zapobieganiu i zwalczaniu chorób, diagnozowaniu, leczeniu, a tam, gdzie to tylko możliwe, przywróceniu do zdrowia; na pocieszaniu w każdej sytuacji; na usuwaniu szkód, łagodzeniu cierpień, dodawaniu otuchy; krótko mówiąc: na podtrzymywaniu dobrej kondycji fizycznej, czyli życia. Wszystko, co staje na przeszkodzie w osiągnięciu tego celu, musi zostać odparte, zagraża to bowiem bazowemu obrazowi wyobrażeniowemu [w oryginale: root metaphor ${ }^{5}$ - przyp. T.S.]: podtrzymywaniu życia. Tam, gdzie poszczególne cele są nawzajem sprzeczne - usunięcie szkody przysparza bólu, ból działa leczniczo lub łagodząca morfina wywołuje chorobę - trzeba zbudować hierarchię wartości. Ale wartością najwyższą w tej hierarchii jest zawsze podtrzymywanie życia ${ }^{6}$.

${ }^{3}$ Zob. np. M. Seligman, E.F. Walker, D.L. Rosenham Psychopatologia, przeł. J. Gilewicz, A. Wojciechowski, Zysk i S-ka, Poznań 2003, s. 19 i n. oraz J. Raden (ed.), The Philosophy of Psychiatry. A Companion, Oxford University Press, New York 2007, s. 329-409.

${ }^{4}$ S. Pużyński (red.), Leksykon psychiatrii, dz. cyt., s. 418.

5 Zob. J. Hillman, Suicide and the Soul, Spring Publications, Putnam-Connecticut 2007, s. 34 .

${ }^{6}$ Tenże, Samobójstwo a przemiana psychiczna, przeł. Dariusz Rogalski, KR, Warszawa 1996, s. 33 . 
Także socjologia, prawo i teologia mówią w kwestii samobójstwa zaskakująco jednomyślnym głosem. Każda z tych dziedzin - tak, jak medycyna - projektuje własną siatkę norm, własną hierarchię wartości, u podstaw której zawsze stoi jakaś źródłowa metafora, podstawowy obraz, wokół którego - i ku któremu - budowana jest struktura pojęciowa danej dyscypliny. We wszystkich wspomnianych przypadkach źródłowe metafory - „społeczeństwo", "prawo", "boski porządek" - radykalnie wykluczają samobójstwo. Sprzeciwiają się mu jako czemuś, co stanowi gest par excellence anarchiczny, stawiający jednostkę poza zasięgiem wpływu tak czy inaczej pojmowanej zbiorowości, albo tak czy inaczej pojmowanego suwerena. Wszystkie te dziedziny - mówiąc innymi słowy - przystępują do rozumienia czy też raczej potępienia samobójstwa całkowicie z zewnątrz. Zainteresowane są wyłącznie utrzymywaniem własnej spoistości oraz egzekwowaniem spełniania generowanych przez siebie norm - nie mają natomiast (bo nie chcą i nie mogą mieć) dostępu do realnego zjawiska. Taka konfrontacja zmusiłaby je do zredefiniowania własnych podstaw, własnych źródłowych metafor. Tym samym $\mathrm{w}$ trosce o zachowanie status quo - obcują wyłącznie $\mathrm{z}$ własnymi fantomatycznymi przedstawieniami.

Szczególnie uderzające zapoznanie rzeczywistości samobójstwa dostrzega Hillman w obszarze teologii - dyscyplinie, wydawałoby się, w sposób szczególny związanej z psyche, z duszą, której ponowne odkrycie jest kamieniem założycielskim współczesnej psychologii głębi

Teologia chce - pisze Hillman - byśmy wierzyli, że Bóg potrafi przemawiać tylko poprzez ciosy losu, a śmierć może przyjść tylko z zewnątrz. Również z takiej perspektywy śmierć jest - podobnie jak dla socjologii i prawa - bytem egzogenicznym, może nam ją zadać tylko świat zewnętrzny: wróg, nieszczęśliwy wypadek, choroba. Nie nosimy jej w sobie; nie żyje ona w duszy. Czy jednak Bóg nie może przemawiać poprzez duszę, czy nie może żądać czynu zadanego własną ręką? Czy nie jest pychą teologii,

7 Zwłaszcza psychologia analityczna Carla Gustava Junga - którego Hillman był uczniem - przyczyniła się do ponownego „przebudzenia” i odkrycia rzeczywistości psychicznej, duszy, tego "trzeciego czynnika" obok materii i ducha (czyli intelektu), który z perspektywy psychologii jest najważniejszy i pierwotny. Rzecz jasna, mówiąc o duszy, Hillman nie ma na myśli jakiejś nierozciągłej substancji (na podobieństwo Kartezjańskiej res cogitans), albo subtelnego bytu. Podkreśla wielokrotnie, że „pisząc o duszy ma na myśli raczej pewną perspektywę, a nie substancję, raczej sposób postrzegania rzeczy, niż rzecz samą". Ta perspektywa jest refleksyjna - dodaje a także w szczególny, w pewnym sensie religijny sposób związana z miłością i śmiercią. Nie da się jej w żaden wyraźny sposób zdefiniować czy oddzielić od tego, co się zdarza - choć właśnie poprzez duszę to, co się zdarza, staje się znaczące. Dusza, mówi Hillman, przemienia zdarzenia w przeżycia, czy raczej nadaje zdarzeniom głębi, która sprawia, że stają się przeżyciami. Dusza jest także tożsama z wyobraźnią, z imaginatywnym potencjałem ludzkiej natury - jest tym, co fantazjuje, śni, postrzega rzeczywistość jako przestrzeń przed wszystkim obrazową, symboliczną i metaforyczną. Dusza jest więc - last but not least - przestrzenią doświadczenia, doświadczenia zarówno najbardziej subiektywnego, jak i przekraczającego subiektywność (zob. J. Hillman, Re-Visioning Psychology, dz. cyt., s. XVI i n.). 
by w ten sposób ograniczać boską wszechmoc, że dopuszcza śmierć tylko w sposób nie podważający teologicznego obrazu wyobrażeniowego? Samobójstwo nie przeczy bowiem ani Bogu, ani religii, a jedynie roszczeniu teologii do decydowania, jaką śmiercią mamy umierać ${ }^{8}$.

Tym czterem paradygmatom, czterem modelom myślowym, czterem obszarom definiującym i kształtującym sposób funkcjonowania jednostki w społeczeństwie (wracamy do bazowego dualizmu rodem z Leksykonu psychiatrii), przeciwstawia Hillman perspektywę psychologiczną czy też analityczną. Psychologia głębi - mówi - jest dziedziną autonomiczną, a przynajmniej będącą $\mathrm{w}$ trakcie procesu autonomizacji. Z całą jednak pewnością psychologia głębi - jako dyscyplina, której fundamentalnym datum nie jest ani „społeczeństwo", ani "prawo”, ani „boski porządek”, lecz psyche - już na samym wstępie zakłada w odniesieniu do faktów psychologicznych diametralnie inną metodologię i - co za tym idzie - przyjmuje wobec nich diametralnie inną postawę. Przede wszystkim „,analityczne zbadanie problemu wyróżnia się tym, że ani z góry nie potępia, ani nie usprawiedliwia, ani $\mathrm{w}$ ogóle $\mathrm{w}$ żaden sposób nie ocenia samobójstwa, ale próbuje je zrozumieć jako fakt rzeczywistości psychicznej"9. Analityk - postępując zresztą w duchu „ojca-założyciela” psychologii głębi, czyli Carla Gustava Junga - badając jakikolwiek symptom czy też fenomen psychiczny, stara się przede wszystkim uniknąć przyjmowania postawy normatywnej.

Zamiast wpisywać dane zjawisko w z góry założony system odniesienia czy to sensu stricto moralny, czy też normatywny w mniej otwarty sposób, na przykład operujący wyraźnie zdefiniowanym pojęciem "normy" - analityk próbuje odnaleźć jego psychologiczny, wewnętrzny sens. Próbuje umiejscowić je w symboliczno-psychologicznym układzie znaczeń określającym tożsamość pacjenta, jego osobistą historię czy raczej historię "pisaną" z perspektywy duszy, z perspektywy "lewej ręki"10, a tym samym próbuje odkryć „po

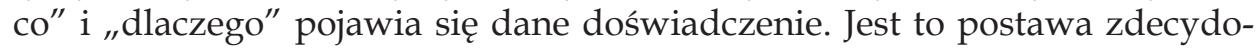
wanie odmienna od postawy medycznej czy teologicznej, które w pierwszej kolejności zakładają, że patologicznego zjawiska nie powinno w ogóle być, w drugiej zaś kolejności poszukują środków mających na celu jego jak naj-

\footnotetext{
8 J. Hillman, Samobójstwo..., dz. cyt., s. 31-32.

9 Tamże, s. 21.

10 Pisząc o analizie i psyche, Hillman kilkakrotnie odwołuje się do metaforyki „prawej” i „lewej” strony - która nie odpowiada jednak psychoanalitycznemu podziałowi na "świadomość” i „nieświadomość”. „Analiza krąży wokół tematów tabu - pisze - i sama stanowi tabu. Cel przystosowania do porządku społecznego jest celem prawej strony, która próbuje go osiągnąć poprzez świadome udzielanie rad. (...) Analiza wspiera lewą stronę w jej dążeniu do świadomego doświadczenia własnego życia bez podporządkowywania się wyrokom prawej strony. Prawa strona nigdy nie może uznać lewej strony taką, jaką naprawdę ona jest, może ją jedynie zinterpretować według własnych kryteriów" (tamże, s. 10).
} 
szybsze wyeliminowanie. Analityk natomiast „zakłada istnienie zrozumiałej indywidualnej osobowości każdego człowieka, do której odnosi się samobójstwo i poprzez którą można je zrozumieć. Dostrzega w każdym ludzkim wydarzeniu to, co intencjonalne. Poszukuje sensu"11.

Poszukując sensu, rezygnując z prostych kwalifikacji i moralistyki, podążając - bez z góry założonego celu, bez z góry obranego punktu dojścia - za spontanicznymi obrazami psyche, przyjmując, że rzeczywistość psychiczna jest wobec uroszczeń teologiczno-medyczno-prawno-społecznych niepodległa, analityk usiłuje wyświetlić znaczenie samobójstwa dla duszy. Dlaczego się ono pojawia? Dlaczego właśnie w tym momencie życia? Jakie dążenie wyraża? Jaką potrzebę próbuje zaspokoić?

\section{2.}

Śmierć i życie (lub egzystencja) - prowokacyjnie oznajmia Hillman - mogą się wykluczać z punktu widzenia filozofii racjonalnej, jednak z punktu widzenia psychologii nie stanowią przeciwieństwa. Śmierci można doświadczyć jako stanu egzystencjalnego (...). W marzeniach sennych i stanach psychotycznych możemy przeżywać koszmar lęku przed śmiercią, możemy czuć się martwi; wiemy to i czujemy ${ }^{12}$.

Ta konstatacja jest nie tylko próbą opisu doświadczenia, jest także skromnym i pozbawionym rozbudowanej teoretycznej podbudowy metodologicznym manifestem. Czy raczej próbą umiejscowienia, a nawet umocowania, refleksji psychologicznej w - cokolwiek wprawdzie proteuszowym, ale jednak konkretnym - uniwersum subiektywnego doświadczenia. Pisząc o psyche czy też o duszy, Hillman nie korzysta z żadnych badań statystycznych, nie odwołuje się do empirycznych eksperymentów, nie interesują go także nawet najbardziej spektakularne osiągnięcia neurobiologii (choć oczywiście w latach 60. ubiegłego stulecia nie była ona nawet w $10 \%$ tak rozwinięta jak dzisiaj - zaledwie cztery lata przed publikacją Samobójstwa... ukazała się słynna książka Thomasa Szasza The Myth of Mental Illness, którą traktowano wówczas jeszcze dość poważnie, a w każdym razie podejmowano z nią merytoryczną dyskusję; rozwój neuronauk skazał Szasza praktycznie na zapomnienie). Tym, co go interesuje jest natomiast subiektywne doświadczenie - symptomy, lęki, fantazje, klęski, załamania, obawy, przeczucia, emocje, myśli - oraz jego rozmaite obiektywizacje, $w$ tym szczególnie obiektywizacje mitologiczne. $W$ jednej ze swoich najważniejszych prac, a mianowicie w książce The Dream and the Underworld - stanowiącej z jednej strony fundamentalną polemikę z Freudowsko-Jungowskim paradygmatem analizy marzeń sennych, z drugiej zaś próbę

\footnotetext{
11 Tamże, s. 43.

12 Tamże, s. 66.
} 
wykazania pełnej tożsamości pomiędzy światem snów a królestwem Hadesu (czy raczej próbę wykazania, że mitologiczny obraz Hadesu jest opisem snu, sen zaś jest "zstąpieniem” w świat podziemny) - Hillman wprost przedstawia swoje credo. Brzmi ono: „Mitologia jest psychologią antyku. Psychologia jest mitologią współczesności"13. Chcąc zatem zrozumieć dynamikę psychologiczną współczesnego człowieka, należy sięgać do mitologii, każde bowiem indywidualne życie w ten czy inny sposób odzwierciedlone jest w mitach. Mit stanowi imaginatywną matrycę doświadczenia - nasze życie naśladuje losy postaci mitycznych. W formie skondensowanej, archetypowej, symbolicznej, mitologia zawiera całość możliwego ludzkiego doświadczenia - jest przy tym także swego rodzaju lustrem, w którym możemy zobaczyć, że nasze indywidualne losy, choć przywiązujemy się do nich i postrzegamy je jako niepowtarzalne, są w gruncie rzeczy mitologicznymi metaforami.

3.

Duszę odnajdujemy przede wszystkim w lęku, rozpaczy, depresji, prześladujących nas obrazach szaleństwa, dokuczliwych symptomach, doświadczeniach całkowitej utraty kontroli nad kapryśnymi kolejami życia, niepokojących marzeniach sennych, chorobie, nieszczęśliwej miłości, kryzysie... Poczucie tragizmu życia, niekompletności, niezaspokojenia, ograniczenia, nostalgii za czymś bezpowrotnie utraconym, niemożliwym do osiągnięcia - wyzbyte tak charakterystycznej dla egzystencjalizmu heroiczności (którą Hillman kwalifikuje jako w pierwszej kolejności „ego-iczność” - jest esencjalnym doświadczeniem duszy. Dopiero człowiek wytrącony z automatyzmu codzienności - z samsary i mai skutecznie wzmacniających witalistyczną, jednostronną świadomość, całkowicie pozbawioną otwartego odniesienia do śmierci, choroby, niedoskonałości i cierpienia (tak naszego własnego, jak i cudzego - które staje się wyłącznie obrazem na ekranie telewizora, albo stygmatem relegującym cierpiących ludzi czy zwierzęta poza granice "zdrowego" społeczeństwa), dopiero zatem człowiek wytrącony z automatyzmu codzienności poprzez załamanie nerwowe albo załamanie kariery, dokuczliwy symptom, bezsenność, depresję, chorobę, zdradę czy rozstanie - staje na drodze duszy. Czy raczej: inicjacja w rzeczywistość duszy - czasami prowokowana przez samą duszę, odtrąconą, wprzęgniętą w psychopatyczną, maniakalną gonitwę ego za pieniędzmi, sławą, zbawieniem, podbojami seksualnymi oraz innymi "szczytowymi” doświadczeniami, charakteryzującymi poszukiwania jednostronnie duchowe, represjonujące duszę jako coś "gorszego", "słabszego", "tkliwego", a czasami wręcz „diabelskiego" - staje się

${ }^{13}$ J. Hillman, The Dream and the Underworld, Harper Perennial, New York 1979, s. 23. 
możliwa dopiero po $(\mathrm{i}-\mathrm{w})$ doświadczeniu upadku, kryzysu czy załamania. Paradygmatem takiego kryzysu czy załamania jest, według Hillmana, właśnie kryzys samobójczy. Poprzez dążenie do samounicestwienia - jak uważa interesujący nas badacz - psyche próbuje się „przebudzić” czy raczej próbuje odzyskać łączność ze śmiercią, a więc z tym mrocznym aspektem, ciemnym wymiarem egzystencji, o którym ego próbuje za wszelką cenę zapomnieć, i który stara się ze wszystkich sił (choć są to wysiłki płonne) wyeliminować ze świadomości. Rzecz jasna - jednostka doświadcza tego ruchu duszy jako czegoś kompletnie autonomicznego wobec świadomości. Kryzys samobójczy przejawia się $\mathrm{w}$ mroku depresji, $\mathrm{w}$ gwałtownym ataku melancholii, $\mathrm{w}$ ciążeniu - jak pisze Hillman - ku ciemnemu i zimnemu szkieletowi rzeczywistości. W mgnieniu oka rozbija on w drzazgi iluzoryczną samosterowność ego.

Tym jednak, co w kryzysie samobójczym najgłębiej obecne, jest potrzeba doświadczenia śmierci. A za dosłownie rozumianą śmiercią - pojmowaną początkowo jako literalne uśmiercenie ciała - stoi jeszcze inna potrzeba, a mianowicie: potrzeba radykalnej przemiany.

Fantazje samobójcze uwalniają od powszechnego i tradycyjnego patrzenia na rzeczy, umożliwiając spotkanie z rzeczywistością duszy. Rzeczywistość ta jawi się w formie obrazów, głosów i impulsów, z którymi można się komunikować. Takie spotkania ze śmiercią wymagają uznania królestwa duszy - z jej nocnymi duchami, osobliwymi emocjami i bezkształtnymi głosami, w których życie nie ma ciała i jest w dużej mierze bytem autonomicznym jako rzeczywistości. Wówczas to, co pozornie jest impulsem regresywnym, może ujawnić swoje pozytywne wartości (...). Samobójstwo to popęd do pośpiesznej przemiany. Nie jest ona przedwczesną śmiercią, jak uparcie twierdzi medycyna, ale spóźnioną reakcją życia, które w trakcie swojego trwania nie poddało się przemianom. Chce ono tu i teraz całkowicie umrzeć, gdyż przegapiło wcześniejsze kryzysy śmierci, które je dotknęły. Ta niecierpliwość i nietolerancja to cechy odzwierciedlające stan duszy, która nie dotrzymała kroku życiu lub - w wypadku starych ludzi - życie, które nie może już zaoferować wciąż głodnej duszy żadnego pożywnego doświadczenia. Starzy ludzie muszą zmazać winę i odpokutować za grzech, sami sobie wymierzając karę. Żona zmarła; brak pewności co do ponownego spotkania w zaświatach, ale jest ono przynajmniej niewykluczone, podczas gdy w tym życiu nic już nie nastąpi prócz rozpaczy. Albo też ktoś żyje tak, jakby już umarł, w apatycznym zobojętnieniu: „Jest mi obojętne czy żyję, czy nie”; tutaj dusza już opuściła świat, w którym ciało jeszcze się porusza niby marionetka. We wszystkich tych przypadkach czas wypadł z posad, a samobójstwo przywróci go na właściwe miejsce ${ }^{14}$.

14 J. Hillman, Samobójstwo..., dz. cyt., s. 76-82. 
W każdym razie, samobójstwo wyraża poczucie, że życie w aktualnej postaci nie ma dalszej racji bytu. Śmierć musi nastąpić, ponieważ dalsze trwanie jest niemożliwe. $W$ tym sensie tradycyjna, prewencyjna postawa medycznopsychologiczna, jest $w$ istocie przeciwskuteczna. Uniemożliwiając człowiekowi psychologiczne doświadczenie śmierci (które ma szanse pojawić się tylko wówczas, jeśli impuls samobójczy nie zostanie przedwcześnie stłumiony) paradoksalnie, skazuje go właśnie na śmierć. Postawa analityka natomiast postawa, która nie lęka się śmierci ani samobójstwa, postrzega je bowiem jako nieodłączną składową egzystencji, jako immanentną możliwość, nie mniej „naturalną" niż śmierć ze starości czy śmierć w wypadku samochodowym jako jedyna umożliwia (choć nigdy nie ma pewności, że się to uda) zaistnienie doświadczenia śmierci zanim jeszcze nastąpi śmierć dosłowna.

Doświadczenie śmierci - pisze Hillman - może przebiegać na różne sposoby. (...) Samobójstwo jest tylko jednym z możliwych rodzajów; inne to depresja, załamanie, trans, izolacja, intoksykacja i egzaltacja, porażka, psychoza, dysocjacja, amnezja, zaprzeczenie, ból i tortury. Te stany mogą być przeżywane konkretnie lub symbolicznie. Mogą mieć miejsce w zewnętrznej historii życia lub w historii duszy. Dusza zdaje się przywiązywać mniejszą wagę do rodzaju przeżycia, byle to doświadczenie było jej dane. Być może dla niektórych ludzi samobójstwo jest jedynym dostępnym rodzajem doświadczenia śmierci ${ }^{15}$.

Tym, co stanowi w przypadku tendencji samobójczych realny problem, nie jest jednak śmierć, lecz raczej kontaminacja porządku cielesnego i psychicznego. Samobójstwo jest dla wielu ludzi jedynym dostępnym rodzajem doświadczenia śmierci, ale nie chodzi w nim o literalną śmierć ciała. $W$ tym kontekście - śmierć ciała jest metaforą, którą pogrążona w kryzysie samobójczym jednostka traktuje jako dosłowną prawdę, inaczej bowiem psychologiczne doświadczenie śmierci nie miałoby żadnej szansy, żeby zaistnieć w świadomości. I dopiero rozpoznanie metaforyczności tego pragnienia jest właściwym przebudzeniem duszy - jest więc aktem narodzin człowieka psychologicznego, a zatem człowieka uwolnionego od przygniatającego poczucia dosłowności jednostronnie, biologistycznie pojmowanego życia. Jest aktem narodzin człowieka inicjowanego w śmierć i ciemny aspekt rzeczywistości, człowieka w radykalny sposób akceptującego najbardziej intymne i bolesne uwikłania czy fantazje wyobraźni - traktującego je jako wyraz żywego doświadczenia duszy, duszę zaś postrzegającego jako najbardziej pierwotną, najbliższą, najgłębszą przestrzeń doświadczenia.

Narodziny człowieka psychologicznego czy też - jak nazywa to Hillman gdzie indziej - rewolucja w imię duszy ${ }^{16}$, zaczynają się $\mathrm{w}$ momencie porzucenia nadziei, w momencie rozpaczy, która wymownie ujawnia świadomości

\footnotetext{
15 Tamże, s. 95.

${ }^{16}$ J. Hillman, Re-Visioning Psychology, dz. cyt., s. 99.
} 
jej fundamentalną bezradność, jej podatność na zranienie, lęk i melancholię. To swoiste ogołocenie świadomości ze wszystkich niemal heroicznych cech czy raczej heroicznych iluzji, nie jest jednak tożsame ze stanem głębokiej rozpaczy. Rozpacz bowiem jest wedle Hillmana równie heroiczna czy egoiczna, co maniakalny witalizm - jej podstawową treścią jest przecież pragnienie przekroczenia uwarunkowań skonfrontowane z niemożliwym do sforsowania oporem rzeczywistości. Rozpacz jest punktem wyjścia do przebudzenia duszy - jednak przebudzenie następuje $w$ chwili, kiedy jednostce udaje się opuścić ten wzajemnie napędzający się układ apodyktycznych fantazji wielkościowych oraz wściekłości (czyli rozpaczy), jaką wywołuje niemożność ich spełnienia. Człowiek psychologiczny zatem ani nie marzy o przekroczeniu uwarunkowań, ani nie rozpacza, że nie jest w stanie ich przekroczyć - budowanie świadomości psychologicznej polega raczej na przyjęciu zupełnie odmiennej perspektywy. W jej optyce śmierć i życie, siła i bezradność, przestają być oderwanymi od siebie przeciwieństwami, stają się natomiast rozmaitymi jakościami doświadczenia, które współistnieją ze sobą w jednej przestrzeni, nie zaś wykluczają się nawzajem.

Pozostając wiernym sytuacji braku nadziei, takiej jaka jest, analityk kształtuje rodzaj stoickiej odwagi zarówno w sobie samym, jak i w osobie analizowanej; to zmniejsza groźbę panicznych zachowań. Oboje patrzą w bezruchu na życie i śmierć lub życie albo śmierć. Nie odbywa się żadne leczenie, ponieważ nie mają już żadnej nadziei, żadnych oczekiwań i pragnień. Opuścili świat i jego zewnętrzny punkt widzenia, przyjmując za jedyną rzeczywistość powstające w psyche obrazy, emocje i znaczenia. Śmierć już nastąpiła, gdyż przeminęła żądza życia. Zewnętrzna historia życia rejestruje, że "nic się nie dzieje”, a tymczasem historia duszy może zbierać doświadczenia głębokie i wolne od świata. (...) Tego typu czujność oznacza również zwracanie uwagi na absurdalne i trywialne szczegóły życia. Albowiem doświadczenie śmierci jest nie tylko wielkie, doniosłe i uwolnione od świata, ale rozkłada sprawy codzienne w bezsensie. Wszystko może się zdarzyć; cuda i błędy równocześnie. Jednak taka skrupulatna obserwacja szczegółów nie powinna być wykorzystywana w intencji terapeutycznej: by "pomóc życiu trwać nadal” lub by „wesprzeć ja”. Samo doświadczenie wydobywa z dotychczasowych nawyków całkowicie nowe i zdumiewające znaczenia, przemiana przebiega zaś pod znakiem świadomości i paradoksu - tam, gdzie sens i bezsens się przenikają ${ }^{17}$.

\section{4.}

Doświadczenie śmierci jest według Hillmana inicjacją w rzeczywistość duszy. Rozpoznanie permanentnej obecności śmierci - jej apriorycznego wobec każdego działania czy każdej myśli charakteru - jest warunkiem

17 Tamże, s. 104. 
sine qua non przebudzenia duszy. Tego rodzaju doświadczenie - uobecniające się między innymi w snach, w procesie zstępowania do królestwa podziemnego, w którym wszystkie stałe jakości ulegają koagulacji, ego jest tylko jednym $\mathrm{z}$ wielu aktorów na scenie, uroszczenia woli wydają się śmieszne i naiwne, a „forma świata staje się nierzeczywista"18 - w sposób fundamentalny wytrąca jednostkę z codziennej iluzji, otwiera przed duszą niezmierzoną głębie, budzi niedostępną wcześniej wrażliwość, odcina przywiązanie do "tego świata", w zamian odsłaniając wszechobecność świata podziemnego. Życie przestaje być już maniakalną reakcją obronną przeciw realności psyche - staje się świadomą praktyką pogłębiania, rozpuszczania dosłowności, rozpoznawania metaforycznego charakteru każdej postawy, każdego poglądu czy dogmatu usiłującego skrystalizować wymykające się każdej krystalizacji doświadczenie psychologiczne - które uświadamia sobie już teraz swój głęboki, intymny związek ze śmiercią i z umarłymi.

Mitologicznym obrazem opowiadającym o tym fundamentalnym doświadczeniu jest historia uprowadzenia Persefony przez Hadesa - który w greckiej mitologii, co Hillman wielokrotnie podkreśla, utożsamiany był często $\mathrm{z}$ chtonicznym Zeusem: tak jakby Zeus i Hades byli tą samą osobą, a zatem jakby życie i śmierć stanowiły jakości równorzędne, nie zaś swoje radykalne przeciwieństwa (jak to przedstawia zwłaszcza teologia chrześcijańska, w której systemie pojęciowym wciąż jeszcze myślimy i żyjemy) ${ }^{19}$. W stronę świata podziemnego - królestwa rządzonego przez jedynego greckiego boga, którego twarz zawsze jest odwrócona, którego królestwo jest niewidzialne i niepodległe wobec ziemskiego czasu (w Hadesie czas stoi w miejscu - a zatem, pisze Hillman, Hades jest obecny zawsze, w każdym momencie, nie jest więc rzeczywistością po-śmiertną, lecz raczej rzeczywistością symultaniczną wobec życia, obecną w każdej jego chwili - jako jego absolutne a priori ${ }^{20}$ ) - nieuchronnie zwraca się każde ludzkie życie, nieuchronnie odnosi się każde fundamentalne egzystencjalne pytanie, każda aktywność, każda myśl i emocja. Czy raczej: są one w sposób permanentny do Hadesu odniesione już od samego początku swojego zaistnienia. Hades bowiem jest „niewidzialny, a jednak absolutnie obecny”21.

Uprowadzenie Persefony - z kwietnej łąki wypełnionej odurzająco pachnącymi narcyzami wprost do podziemnego królestwa - to mitologiczny obraz inicjacji w rzeczywistość psyche. Dusza i królestwo podziemne są bowiem ze sobą tożsame - wejście w doświadczenie psychologiczne oznacza wejście

18 Zob. Ch. Baudelaire, Padlina, [w:] tenże, Kwiaty zła, Wydawnictwo Literackie, Kraków 1990, s. 81 oraz J. Hillman, The Dream..., dz. cyt., s. 27 i n.

19 „Jako Zeus Katachtonios czy Chtonios - znamy już ten przydomek - był on również "podziemnym Zeusem«, to zaś było tylko innym imieniem Aidesa czy Hadesa" - pisze Karl Kerenyi (K. Kerenyi, Mitologia Greków, przeł. R. Reszke, KR, Warszawa 2002, s. 193).

${ }^{20}$ J. Hillman, The Dream..., dz. cyt., s. 30 i n.

21 Tamże, s. 31. 
w doświadczenie śmierci czy raczej doświadczenie nieustannego umierania, obumierania nadziei, nabierania dystansu do wydarzeń codzienności. Dopóki - mówi Hillman - żyjemy w błogiej nieświadomości, w błogiej szczęśliwości, w błogiej ślepocie na ciemność egzystencji, dopóty nasza świadomość przypomina świadomość (czy raczej nieświadomość) pogrążonej w radosnej zabawie Persefony. Kiedy jednak los brutalnie wyrywa nas z tej narkotycznej drzemki - poprzez nagłe załamanie, depresję, próbę samobójczą, chorobę, zdradę czy śmierć kogoś bliskiego - stajemy się w jednej chwili uprowadzoną Persefoną. Zaczynamy postrzegać życie z perspektywy królestwa umarłych $^{22}$. Wówczas rozpoczyna się kształtowanie świadomości psychologicznej - zwrot do wewnątrz, wgłąb, w ciemność rzeczy. Wówczas literalne poczucie tożsamości znika, a na jego miejscu pojawia się dojmująca świadomość metaforyczności „ja” oraz wszystkich jego uroszczeń, pragnień i sądów. Persefona rozpacza i tęskni do utraconej niewinności, jednak rekonstrukcja świadomości sprzed uprowadzenia jest już niemożliwa.

Gdy wskutek starań Demeter Hades zgadza się na powrót Persefony na ziemię, wkłada jej do ust słodkie pestki granatu - raz skosztowawszy pokarmu nocy, Persefona zawsze już będzie funkcjonować w dwóch światach równolegle. Przez jedną część roku będzie musiała przebywać u boku Hadesa - przez trzy części roku będzie zaś mogła przebywać wśród ludzi, jednak jej pierwotna niewinność i naiwność zostały definitywnie utracone.

Jak jednak pisze Hillman: „Gwałt dokonany przez Hadesa na niewinnej duszy jest konieczny dla przemiany psychicznej”23.

\section{Suicide: death as a radical transformation}

Sum mary

In this article the author tries to examine the idea of suicidal tendencies and their meaning for the soul - in the context of James Hillman's archetypal psychology. In his groundbreaking book entitled Suicide and the Soul Hillman shows that the medical model - in which suicide is always seen as something pathological - is not sufficient for understanding this phenomenon. Rather than it being a pathology, says Hillman, suicide is just one of the possibilities that every human can choose from. The most important question is why the psyche would want to enter into the death experience? Hillman says that the suicide impulse is actually a hidden desire for a radical existential, spiritual and psychological change. If one lets this change happen in the process of analysis, i.e. if one lets in the experience of death without medicalizing and pathologizing it - a literal death of the body is no longer necessary. Death - like the mythological Hades - is always present and that is why the "death experience" is psychologically real, although logically paradoxical.

\footnotetext{
22 J. Hillman, Re-Visioning Psychology, dz. cyt., s. 208-209.

23 Tamże, s. 208.
} 
